'encyclopædia work' practised in a London junior school? The observations on the junior schools note many omissions in science. Even if wo agree that somo of Mr. Wells's ideas are beyond young folks, some of the simpler work is disappointing; in elementary physiology, for example, questions about seeds and animals. Tho senior schools do not supply many records, but those given are elaborate enough to suggest the need for real refresher courses for teachers. Interest in science of somo sort may bo rezarded as universal. Unfortunately it is not, and whoro teachers lack interest they aro not likely to provide the stimulus which leads to permanent keenness in their pupils.

\title{
EDUCATION AND INDUSTRY
}

\begin{abstract}
$\mathrm{T}$ HE discussion on education as a preparation for industry which followed Dr. A. P. M. Fleming's presidential address on education for industry to Section I (Educational Science) of the British Association, delivered on August 31, was opened by a paper, read in his absence, by Mr. IV. O. Lester Smith, director of education of Manchester, who stressed the importanco of a sound general education and the significance of Hadow reorganization. Our educational neglect of the adolescent has led to wastage of human material. The wanton blow struck at the day continuation school clauses of the Fisher Act by the 'Geddes Axe' was probably the unkindest cut our educational system has ever suffered; it has prevented local authorities from making a satisfactory job of the youth problem.
\end{abstract}

Discussing the organization of technical education, Mr. Lester Smith referred to the value of regional co-operation and the necessity for a constant revision of the subject-matter of technical education to meet tho needs of a competitivo and scientific age. Although the Trades Union Congress adopted a cautious attitude to somo modest suggestions in the Spens report for the infusion of technical teaching into the later stages of tho secondary school curriculum, there aro signs of $\mathbf{a}$ chango in outlook. Employers aro more disposed to seo value in general education, and teachers are appreciating moro fully the additional interest which an occupational bias can give to the last stage of school life. There is no strong evidence, however, in tho post-graduate work in universities of $a$ desire to assist industry to grapple with new problems. Industry as a career is regarded as a side-line, and industry and commerce will continue to roly mainly for its personnol, both leaders and rank and file, upon the less academic institutions and schools administered by local authorities. Finally, Mr. Lester Smith referred to the importance of facilities for training technical teachers and providing for the adequate dissemination of knowledge of new processes or of the achievements of research.

Sir Richard Gregory described opportunities open to apprentices at Portsmouth dockyard, while Dr. K. Fisher, headmaster of Oundle School, referring to the criticism of public schools that they give their pupils no chance of contact with the rest of the youth of the country, suggested that compu sory national sorvice may remove that disability. Public schoolboys and other youths may thus become conscious of a common bond. Moreover, employers are increasingly anxious to find public schoolboys to enter their service.

The allied discussion on education in industry, which followed on September 1, was opened by Mr. J. D. Langmuir, who emphasized the responsibility and obligation of all who employ young workers to see that they have adequate practical and technical training to suit thoir abilities. The narrow specific workshop or office training should be provided by the employer, but the responsibility for technical training should be shared with those responsible for education. There is little or no organized and systematic workshop training in Scotland, and the position of technical education is equally unsatisfactory. There has been no co-operation between education and industry, and real progress in technical education is impossible in its absence and until employers tako moro intorest in both day-school and tochnical education.

After criticizing both Scottish day-school and technical education, Mr. Langmuir advocated a bolder policy of grading, which would givo the pupil free choico of a courso suitable for his occupational desires. A boy with an occupational objective is more likely to remain to obtain the certificate which would facilitate entrance to his chosen career. Education should bo less bookish; attempts to convert secondary schools into miniature universities resisted. Supporting the idea of the junior technical school, he pleaded for closer co-operation with industry on the lines of the Edinburgh continuation class scheme. He stressed the obligations of employers for technical education of young workers and the limitations of works schools, and he also discussed the possibilities of introducing day continuation classes. Beforo this is possible, he said, leaders of industry and commerce must recognize the importance of such education. In technical education we are far behind Belgium, Denmark and Germany, and the provision of a wellthought-out scheme of technical education for the rank and file of our workshops and commercial houses is long overdue.

A written communication by Mr. G. L. Darbyshire, of the London Midland and Scottish Railway, which was read by Dr. Fleming, described the methods of recruitment and qualifications required for engagement by that company, as well as the training arrangements, both internal and external. In addition to classes for.instruction in such special branches as block signalling, locomotive working, permanent way maintenance, etc., and lectures on special problems arranged internally, the staff are encouraged to proceed in further education. Films as well as departmental publications are used freely for instructional purposes.

Discussing part-time education outside the works, Principal J. Cameron Smail, of the Heriot Watt College, Edinburgh, reforred to the strain on individuals involved by part-time education in ovening classes, although the results have justified the method. The outstanding results achieved with day classes in the dockyard scheme, however, have shown the 
possibilities of a daytime system for educated students; the psychological value of the sandwich system is also insufficiently appreciated and merits further investigation. Principal Smail referred to the danger of taking too narrow a view of technical training, to difficulties of staffing and equipment and to the importance of full contact between teachers in technical schools and current workshop and factory practice.

Dr. F. J. Chapman, of the Board of Education, stated that the most urgent educational problem before industry in Great Britain at present is the training of craftsmen. For craftsmen, as well as for technologists and managers, training involves tho learning of techniques, the acquisition of skill and the study of technology. The main problem in the first is the apportionment of the training required between systematic instruction in schools on one hand and practical experience on the other; and in regard to the second, the best methods of co-operation between industry and educational institutions.

Mr. S. E. Goodall described the form of apprenticeship developed by the Metropolitan-Vickers Electrical Co. Ltd., while the concluding paper, by Prof. Willis Jaclson, dealt with post-advanced education. During the past few years, provision for post-graduate practical training has been considerably extended, and on the electrical side of engineering practically every firm of note has now introduced $n$ scheme of post-graduate apprenticeship. In excoptional circumstances only aro graduates recruited direct to technical or other positions. It is now widely recognized by industrial concerns that tho primary function of university courses in applied science is not to provide them with ready-made specialists, but rather to develop the ability to think deeply and critically in terms of those fundamental principles which underlie all tho specialized branches of a particular applied science.

One of the advantages of the post-graduate apprenticeship system lies in the opportunity it affords for the acquisition of general engineering knowledgo as well as specialized information. Tho ability to acquire information by such independent effort is one of the greatest assets which a man can possess, and one which our educational institutions should seek to develop. In this connexion, the recent development in local areas of post-graduate courses of instructiontermed post-advanced courses, since they also servo the needs of men who have proceeded through part. timo evening courses to Higher National Certificates $\longrightarrow$ of a specialized technological character appropriate to the industrial needs of those areas, is of special value. Prof. Jackson outlined certain of theso courses and stressed the educational significance of the success and extension of such schemes.

\section{WORK OF THE FORESTRY COMMISSION}

$I^{N}$ the nineteenth annual report of the Forestry Commission for the year ending September 30, 1938 (London: H.M. Stationery Office, 1939), there are some interesting particulars on private forestry. Seven eighths of the woodlands in Great Britain, it is stated, are privately owned.

Early in 1938 tho Commissioners commenced a census of all private woods, a field staff of sixteen being employed on the work. 'This undertaking was being carried out by trained men, data regarding area, type, age, condition, species, volumo by species and girth classes of each unit of woodland being recorded. So far, 613,000 acres had been dealt with. Although tho visits of Government officials on private estates are never greeted with unmixed approval, yet it may bo said for this piece of bureaucratic work that the results aimed at justify the means adopted. Both in the national interests and in those of the private owner the information obtained will bo invaluable. Many private owners of woodlands were aware that their property of this type was by no means yiclding an adequate return; whilst a considerable percentage, through neglect and ignorant management, brought in no return whatsoever. The remission of taxation of young, properly grown woodlands which cannot in the nature of things bring in any return to the planter until they have reached a marketable value-usually a certain dimension-is understandable and mere justice. But there appears little justification to grant remission of this type on areas of poor and neglected woodland the marketable value of which is nil. From statements in this report and articles in the Press, it is evident that landowners have become alive to this problem and are endeavouring to come to an understanding upon a broad forest policy to be followed. That this is a necessary preliminary step is demonstrable. For when all is said and done, as the Continent of Europe well shows, the policy of a State forest department is not in all particulars adapted to the private owner ; and is often quite impracticable for such.

The report has somo interesting remarks to make upon amenity, the New Forest, and national parks, all of which have already been noted in Nature.

The total addition to the woods of Great Britain through the operations of the Commission during the year under review was 20,300 acres, approximately 51 million trees being planted; of these, 47 per cent were Norway and Sitka spruce, 24 per cent Scots and Corsican pine, 9 per cent European and Japanese larch, 1 per cent Douglas fir and 16 per cent broad-leaved species.

The public, through the Commissioners, owned 125 forests in England and Vales and 107 forests in Scotland. The total area afforested during tho nine. teen years of the Commission amounts to 365,000 acres. Some of the earlier planted areas are now having the first thinnings made in them. The total area now controlled by the Forestry Commission in Great Britain amounts to $1,100,000$ acres.

The year under record had some dangerously dry periods in it, commencing as early as late February in parts of Great Britain. Consequently the firo danger and damage were serious, being the worst year on record for the Commission except for 1929. Tho Commission attributes the damage done to railways and the general public. 